\title{
GREEK MYTHOLOGY AS SEEN IN RICK RIORDAN'S THE LIGHTNING THIEF
}

\author{
Muhamad Nurul Hikmat
}

\begin{abstract}
Abstrak
Novel karya Rick Riordan yang berjudul The Lightning Thief ditulis berdasarkan mitologi Yunani. Mitologi tersebut merupakan manifestasi kebudayaan bangsa Yunani yang berumur lebih dari ribuan tahun. Untuk mengungkap representasi mitologi Yunani dalam The Lightning Thief sebagai suatu manifestasi kebudayaan, kajian dan analisis dilakukan melalui pendekatan struktural dinamis dengan berfokus pada struktur faktual (plot, karakter, dan seting) dari novel tersebut. Plot dalam novel berasal dari tiga cerita ksatria Yunani. Karakter-karakter yang ada dalam novel melibatkan empat karakter mitologis yang memiliki peranan penting di antara dua puluh tujuh karakter mitologis yang ada dalam novel, karakter tersebut meliputi empat manusia setengah dewa, lima dewa, satu Titan, serta tujuh belas makhluk mitologis. Adapun dalam seting terdapat dua tempat yang berkaitan dengan mitologi Yunani.
\end{abstract}

Kata Kunci: Representasi, Mitologi Yunani, Plot, Karakter, Seting

\begin{abstract}
The novel by Rick Riordan entitled The Lightning Thief is written based on Greek Mythology. This mythology is The Greek's manifestation of culture that ages thousands years. To reveal the representation of Greek Mythology in The Lightning Thief as a cultural manifestation, study and analysis is conducted through dynamic structuralism approach focusing on plot, characters and settings (factual structure) of the novel. The plot is originated from three Greek heroes' stories. The characters involve four significant mythological characters out of twenty seven mythological characters in the novel including four demigods, five gods, one Titan and seventeen mythological creatures. While in the setting of place, there are two places related to Greek mythology.
\end{abstract}

Keywords: Representation, Greek Mythology, Plot, Characters, Setting

\section{INTRODUCTION}

From 3,000 years ago, Greek religion manages to survive up to present. It is not in a form of religion, but it remains as mythology at the moment. This is called by cultural manifestation of The Greek. Cultural manifestation is a system or a result of cultural concepts as connecting structure of human activities or actions which, according to Honigman (via Koentjaraningrat 200), has three patterns:
1.) Ideas, 2.) Activities, and 3.) Artifacts. The mythology, in this case, is as a result of the religion.

The concepts or ideas of Greek mythology have been inspiration in literature for many literary works. From the ancient ones, there are the Iliad and the Odyssey by Homer ( 800 BC) which contain the early stories of Greek Mythology. While the popular ones such as C. S. Lewis' The Chronicles of Narnia (1950 - 
1956), J. R. R. Tolkien's The Lord of the Ring trilogy (1954 - 1655) and J. K. Rowling's Harry Potter series (1997) explore the characters in Greek mythology to enrich the stories.

Accordingly it is not an excessive statement if Edith Hamilton in her book Mythology (1961) states "the great stories from Greek mythology are the fountainhead of all literature" because how influential the stories in building other new varied stories.

Rick Riordan's The Lightning Thief (TLT) is the first out of five books in the series of Percy Jackson and the Olympians which are based on Greek mythology. The story itself is about a quest of Perseus 'Percy' Jackson, a twelve-year-old demigod, to retrieve Zeus' thunder bolt in preventing chaotic war between gods that has impacts on human life. It is published in 2005 and has been sold over 1.2 million copies in its first four years. It won the New York Times Best Seller and 32 other awards (www.rickriordan.com, "The Lightning Thief"), even up to April 2011 it is still on the list of Children' Series best-selling novel (. "Best Sellers").

Therefore, TLT can be regarded as the manifestation of culture itself that maintains Greek mythology familiar to the people. In the other hand, the novel belongs to popular novel because it is commercially oriented for the masses which can bring a lot of profit to both the author and the publisher.

The present writer believes that Greek Mythology in TLT can be identified through the plot, characters and settings - Robert Stanton defines these elements as the factual structure of novel. This assumption is also based on Stanton's statement that considers those elements "conspicuous" and "fill a story so completely that some readers have trouble seeing anything else" (12). To find out how Greek mythology is depicted in TLT, dynamic structuralism theory by Jan Mukařovský is used. This theory emphasizes:

The work of art manifests itself as [a] sign in its inner structure, in its relation to reality, and also in its relation to society, to its creator and its recipients. (Fokkema 143)

Hence, this paper discusses the inner structure (factual structure) of the novel. However, the relation to reality (Greek mythology) is also mentioned in order to enrich the discussion so that the representation of Greek mythology in the novel can be revealed.

\section{Greek Religion: The Root of Greek Mytho- logy}

The word "Greek", in the form of noun, semantically signifies a native or inhabitant of ancient or modern Greek, or, a person of Greek decent. Further in this paper it is written as "Greeks", "The Greek" or "The Greeks". The word "Greek" also signifies a language used by the Greeks from prehistoric times to the present constituting a branch of IndoEuropean. As an adjective, "Greek" refers to something of or relates to Greek, and also characteristic of Greece, Greeks, or Greek (Merriam-Webster's Dictionary).

The next word is "religion", but it is not easy to define what religion is. In fact when religion becomes the topic of discussion there is no single agreed definition for it. Each religion has its own definition for the word "religion". Even each person may understand "religion" in various ways. The simplest way to find out its definition is by consulting the dictionary. In Merriam-Webster's Dictionary, 
"religion" is signified as: 1.) the state of a religious; the service and worship of God or the supernatural; commitment or devotion to religious faith or observance, 2.) a personal set or institutionalized system of religious attitudes, beliefs, and practices, 3.) , and 4.) a cause, principle, or system of beliefs held to with ardor and faith.

In Sabatier's study, religion is not only a phenomenon of the individual and inner life, but it is also a social and historical phenomenon (89). "Religion is the social institution built up around the idea of a supernatural being or beings and the relation of human beings to them" (Fairchild via Hasim 21). This phenomenon is seen in Greek religion. Greek religion is the religion of the Hellenic people from about $1500 \mathrm{BC}$ to about $500 \mathrm{AD}$ that combines deities and rites of many local cults (Encyclopedia 311), Sabatier called it a "confederation of local cults and deities" (95). Greek religion derives primarily from the religion of the Minoans in Crete (about 2000 $1400 \mathrm{BC}$ ), adopted in part by the Mycenaean princes of Greece (about 1600 - 1200 BC) from the religion of the Greek invaders from the North which is called the primitive Aegeans or the Pelasgians (Encyclopedia 311). From the level of domestic and tribal religion, it succeeded to be the national stage of religion. Then the religious as well as the social consciousness of the people enlarged in Greece (Sabatier 94).

What the Greeks did for religion is in general not highly-esteemed. Their achievement in that field is usually described as unimportant, without any real significance. It has even been called paltry and trivial. The reason people think of it in this way is that Greek religion has got confused with Greek mythology (Hamilton, "Greek Way" 207). Greek religion is now only a myth. A myth people generally know about something to do with natural phenomenon, gods, goddesses, mythical creatures and their interaction with human beings.

This transformation occurred because Greek religion was developed not by priests nor by saints nor by any set of men who were held to be removed from the ordinary run of life because of a superior degree of holiness; it was developed by poets and artists and philosophers, all of them people who instinctively leave thought and imagination free, and all of them, in Greece, men of practical affairs (Hamilton, "Greek Way" 208).

\section{Greek Mythology and the Fact about TLT}

The previous explanation shows that Greek religion is strongly connected to Greek mythology as its origin. Now Greek religion has transformed into Greek mythology. According to Merriam-Webster dictionary, "mythology" contains four meanings, which are: 1.) an allegorical narrative, 2.) a body of myths: as a: the myths dealing with the gods, demigods, and legendary heroes of a particular people $\mathbf{b}$ : , 3.) a branch of knowledge that deals with myth, 4.) a popular belief or assumption that has grown up around someone or something: myth.

Greek mythology mostly concerns with heroic world joined on the historical world of the Greeks in time (Pinsent 11). Many familiar heroes such as Perseus, Oedipus, Heracles, Theseus or Achilles are mentioned in Greek mythology. Greek mythology also explains the theory of the origin of the universe and its natural phenomenon mentioning the gods or demigods and their stories in human world. 
Rick Riordan, the former middle school teacher, successfully blends the contemporary setting with those concepts of mythology in TLT. When Riordan was asked about his big challenge in incorporating Greek mythology into a new story, he answered "in balancing how much the old myth to tell within my story," and explained:

Usually I don't say much. I figure kids will either know the myth, or they will get the Percy version without really needing to know the myth. Often kids will tell me they read Percy then are inspired to pick up mythology books. I think that's awesome. (")

"Greek myth is a subject that really catches kids on fire," Riordan says, although he has not quite yet put his finger on the reason. "I guess because it's still so relevant in our lives. The neat thing for me is to figure out how to do that, to combine the myth with the modern" (.

Riordan confessed that he is inspired by his son, Haley, to write the story. He asked Riordan to tell him some bedtime stories about the gods and heroes. Since Riordan had taught Greek mythology for many years, it was a pleasure to him. Then as he ran out of myths, Haley was disappointed and asked him to make up something new with the same characters.

Off the top of my head, I made up Percy Jackson and told Haley all about his quest to recover Zeus' lightning bolt in modern day America. It took about three nights to tell the whole story, and when I was done, Haley told me I should write it out as a book. (, "Interview with Rick")

In 2004 The Lightning Thief was sold to and it is finally published in 2005. With the subsequent advance and three-book deal, Riordan was able to quit his teaching job at St. Mary's Hall and devote himself full-time to writing the Percy series as well as his detective series set in San Antonio, which has won Riordan the big three of mystery awards, the Edgar, the Anthony and the Shamus (.

\section{Greek Mythology in the Factual Structure of $T L T$}

\section{Structural Analysis}

1.1 Plot

In the broadest sense, "the plot of a story is its entire sequence of events" (Stanton 14). James L. Potter in his book Elements of Literature defines plot as "a sequence of events that constitutes a whole unit separate from the happenings that precede or follow it" (24). In $T L T$ the story begins with the appearance of a Fury in Percy's fieldtrip, not with Percy's birth, and it ends with Percy's triumph to retrieve the bolt followed by the prophecy that comes true without mentioning the subsequent events of Percy's life.

The plot of a story consists of a beginning, middle and end (Stanton 14). Based on this classification, the present writer divides the plot of $T L T$ into three parts:

1. Beginning: Percy was accused of stealing Zeus' Master Bolt and was foreshadowed by the Oracle's prophecy (Chapter $1-9)$.

2. Middle : Percy's quest to find Zeus' Master Bolt (Chapter 10 - 20).

3. End: Percy's triumph to bring the Master Bolt back to Zeus and the fulfillment of the prophecy (Chapter $21-22$ ).

The type of the plot in TLT is known in popular literature studies as literary formula. 
Literary formula is "a structure of narrative or dramatic conventions employed in a great number of individual works" that also can refer to a plot type of a story (Cawelti 5). In an adventure story as in $T L T$, the formulas are:

1. "...The hero - individual or group - overcoming obstacles and dangers and accomplishing some important and moral mission" (39). Percy has succeeded to overcome the obstacles and dangers on his quest and to accomplish his mission retrieving Zeus' Master Bolt that prevents the war among the gods.

2. “...The hero's trials are the result of machinations of a villain, and, in addition, the hero frequently receives, as a kind of side benefit, the favors of one or more attractive young ladies" (39-41). Percy's quest is the result of Kronos who agitates Luke and Ares to operate his schemes. They set Percy so he takes the blame of stealing the bolt. Though, in a positive point of view, Percy becomes involved in an ambiguous friendship with Annabeth.

3. "It [the adventure story] presents a character, with whom the audience identifies, passing through the most frightening perils to achieve some triumph [sic]" (40). Percy's victory over his quest to bring the Master Bolt back to Zeus also belongs to the formula that constitutes in the adventure story. Not only giving back the bolt, Percy's other triumphs are also to fail the rise of Kronos, to prevent the war between gods, to meet his true father and to bring his mother back to life.

4. The hero can be categorized: "as a super hero with exceptional strength or ability or as 'one of us' . . . by flawed abilities and attitudes presumably shared by the audiences" (40). Further analysis is elaborated in the section of "Characters".

5. The hero needs a movement geographically or in mind (Adi, "Popular Literature"). Further analysis is elaborated in the section of "Settings".

\subsection{Character}

There are two types of hero in an adventure story according to Cawelti, the superhero and the ordinary hero (40). The hero in $T L T$ is Percy Jackson, a demigod, the son of Poseidon. Percy is "a superhero with exceptional strength or ability" (40) such as his ability to control the water around him, his self-healing ability by touching the water, also his ability to breathe and keep dry underwater.

The term "character" is used in a way it designates the individuals who appear in the story (Stanton 17). There are TLT characters relate to Greek mythology and some do not. Three characters which do not relate to the mythology are Nancy Bobofit, Sally Jackson and Gabe Ugliano. The table below shows the characters that are related to Greek mythology: 